\title{
Experimental study of the performance of intumescent coatings exposed to standard and non-standard fire conditions
}

\author{
Lucherini, Andrea ; Giuliani, Luisa; Jomaas, Grunde
}

Published in:

Fire Safety Journal

Link to article, DOI:

10.1016/j.firesaf.2017.10.004

Publication date:

2018

Document Version

Peer reviewed version

Link back to DTU Orbit

Citation (APA):

Lucherini, A., Giuliani, L., \& Jomaas, G. (2018). Experimental study of the performance of intumescent coatings exposed to standard and non-standard fire conditions. Fire Safety Journal, 95, 42-50.

https://doi.org/10.1016/j.firesaf.2017.10.004

\section{General rights}

Copyright and moral rights for the publications made accessible in the public portal are retained by the authors and/or other copyright owners and it is a condition of accessing publications that users recognise and abide by the legal requirements associated with these rights.

- Users may download and print one copy of any publication from the public portal for the purpose of private study or research.

- You may not further distribute the material or use it for any profit-making activity or commercial gain

- You may freely distribute the URL identifying the publication in the public portal

If you believe that this document breaches copyright please contact us providing details, and we will remove access to the work immediately and investigate your claim. 


\title{
Experimental study of the performance of intumescent coatings
}

\section{exposed to standard and non-standard fire conditions}

\author{
Andrea Lucherini ${ }^{a, b}{ }^{*}$, Luisa Giuliani ${ }^{a}$ and Grunde Jomaas ${ }^{a, c}$ \\ ${ }^{a}$ Department of Civil Engineering - DTU Byg, Technical University of Denmark (DTU), Denmark \\ ${ }^{b}$ School of Civil Engineering, The University of Queensland, Australia \\ ' School of Engineering, The University of Edinburgh, UK
}

\section{Keywords}

Intumescent coatings, thermal resistance, heating rates, standard and non-standard fire curves, steel protection

\begin{abstract}
Three different experimental setups corresponding to three different fire scenarios were used to investigate how different heating conditions and heating rates affect the behaviour of two different thin intumescent coatings (a solvent-based and a water-based paint). Coated steel samples were exposed to different standard and non-standard fire conditions in an electric oven, in a gas furnace and in a cone heater. A general trend was observed in the thermal resistance development for the tested intumescent coatings, divided into three general phases: inert phase, transient phase and steady phase. The different stages were identified according to four critical points: activation, end of reaction, binder exhaustion and steel austenitization point. The tested water-based paint had better performance for low heating rates, while the tested solvent-based paint had better performance for high heating rates. However, for really low heating rates the solvent-based paint did not activate or provide proper insulation. In summary, the results confirm that the current procedure for the design of intumescent coatings has shortcomings, as different paints have different performances according to the heating conditions and, in particular, according to the fire heating rate.
\end{abstract}

$[\ldots]$

\section{Acknowledgements}

This study was performed at the Department of Civil Engineering of the Technical University of Denmark (DTU) with the partial financial support by COWI Fonden [Grant A-121.35]. The authors would also like to thank Razvan-loan Costa and Jesper Andersen, whose work on this topic in the framework of their M.Sc. thesis provided useful insights to this paper.

\section{References}

[1] J. Dowling, Fire protection costs for structural steelwork, New Steel Construction, United Kingdom, 2003.

[2] G.Q. Li, G.B. Lou, C. Zhang, L.L. Wang, Y.C. Wang, Assess the fire resistance of intumescent coatings by equivalent constant thermal resistance, Fire Technology, vol. 48, pp. 529-546, 2012.

[3] L. Wang, Y. Dong, D. Zhan, C. Zhang, Experimental study of heat transfer in intumescent coatings exposed to non-standard furnace curves, Fire Technology, vol. 51, no. 1, pp. 627-643, 2015.

\footnotetext{
* Corresponding author at: School of Civil Engineering, Advanced Engineering Building (\#49), Staff Road House, The University of Queensland, St. Lucia, QLD 4072, Australia.

Email address: a.lucherini@uq.edu.au (A. Lucherini).
} 
[4] International Organization for Standardization (ISO), ISO834-1, Fire resistance tests - Elements of building construction - Part 1: General requirements for fire resistance testing, Geneva, Switzerland, 1999.

[5] Comité Europeén de Normalization (CEN), EN 13381-8, Test methods for determining the contribution to the fire resistance of structural members - Part 8: Applied reactive protection to steel members, Brussels, Belgium, 2013.

[6] Y. Zhang, Y.C. Wang, C.G. Bailey, A.P. Taylor, Global modelling of fire protection performances of an intumescent coating under different furnace fire conditions, Journal of Fire Science, vol. 31, no. 1, pp. 51-72, 2012.

[7] M. Bartholomai, R. Schriever, B. Schartel, Influence of external heat flux and coating thickness on the thermal insulation properties of two different intumescent coatings using cone calorimeter and numerical analysis, Journal of Fire Materials, vol. 27, pp. 151-162, 2003.

[8] B.K. Cirpici, Y.C. Wang, B. Rogers, Assessment of the thermal conductivity of intumescent coatings in fire, Fire Safety Journal, vol. 81, pp. 74-84, 2016.

[9] C.E. Anderson, D.E. Ketchum, B. Schartel, Thermal conductivity of intumescent chars, Journal of Fire Science, vol. 16, pp. 390-410, 1988.

[10] G.Q. Li, J. Han, G.B. Lou, Y.C. Wang, Predicting intumescent coating protected steel temperature in fire using constant thermal conductivity, Thin-Walled Structures, vol. 98, pp. 177-184, 2016.

[11] A. Elliott, A. Temple, C. Maluk, L. Bisby, Novel testing to study the performance of intumescent coatings under non-standard heating regimes, Fire Safety Science - Proceedings of the Eleventh International Symposium, pp. 652-665, 2014.

[12] J. Kolšek, P. Cesarek, Performance-based fire modelling of intumescent painted steel structures and comparison to EC3, Journal of Constructional Steel Research, vol. 104, pp. 91-103, 2015.

[13] A. Lucherini, Experimental study of the behaviour of steel structures protected by different intumescent coatings and exposed to various fire scenarios, M.Sc. thesis, Department of Civil Engineering, Technical University of Denmark (DTU), 2016.

[14] International Organization for Standardization (ISO), ISO 5660-1: International Standard, Fire tests Reaction to fire - Part 1: Rate of heat release from building products (Cone Calorimeter Method), Geneva, Switzerland, 1993.

[15] European Committee for Standardization (CEN), Eurocode 3: Design of steel structures - Part 1-2: General rules - Structural fire design, EN 1993-1-2, 2005.

[16] A. Bilotta, D. de Silva, E. Nigro, Tests on intumescent paints for fire protection of existing steel structures, Construction and Building Materials, vol. 121, pp. 410-422, 2016.

[17] J.H. Andersen, Experimental study of the thermal resistance of intumescent coatings exposed to different heating rates, M.Sc. thesis, Department of Civil Engineering, Technical University of Denmark (DTU), 2015.

[18] R. Reed-Hill, R. Abbaschian, Physical metallurgy principles, PWS-Kent Publishing, 3rd edition, Boston, 1991.

[19] R.I. Costa, "Thermal resistance of steel profile protected with intumescent coatings", M.Sc. thesis, Department of Civil Engineering, Technical University of Denmark (DTU), 2016. 